\title{
PENDIDIKAN BERBASIS PRODUK DALAM MENINGKATKAN LITERASI ANAK MENUJU GENERASI EMAS 2045
}

\author{
Nurul Lutfhi Aulia ${ }^{1}$, Aswan $^{2}$, Afina Naufalia ${ }^{3}$ \\ Departemen Pendidikan Bahasa dan Sastra Indonesia ${ }^{123}$ \\ Universitas Pendidikan Indonesia \\ Author Correspondence : hikayatashwansha@upi.edu
}

\begin{abstract}
Abstrak
Kualitas sebuah generasi dilihat dari kualitas sebuah pendidikan. Maraknya isu mengenai generasi emas 2045 saat ini, memberikan harapan kepada generasi milenial untuk mempersiapkan generasi emas yang berpendidikan dalam mengahdapi permasalahan dunia yang semakin kompleks. Dalam mempersiapkan generasi yang berpendidikan, diperlukan aspek yang menunjang hal tersebut. Salah satunya adalah keterampilan membaca. Sayangnya, tingkat literasi masyarakat Indonesia, khususnya anak-anak masih di bawah rata-rata. Mengingat pengaruh perkembangan zaman, dapat diprediksi generasi mendatang akan candu teknologi dan melupakan literasi. Agar tidak terjadi hal tersebut, peneliti melakukan penelitian yang bertujuan untuk meningkatkan literasi anak dengan pendidikan berbasis produk. Di zaman globalisasi ini, teknik mengajar konvensional seperti ceramah sudah tidak pas digunakan. Anak harus aktif dan bisa menghasilkan suatu karya. Dengan menjalankan pendidikan berbasis produk, anak akan secara otomatis melakukan kegiatan membaca demi terciptanya suatu produk yang harus dihasilkan. Dari keterpaksaan tersebut, peneliti yakin anak-anak akan terbiasa melakukan kegiatan literasi. Dalam melakukan penelitian ini, peneliti menggunakan metode kualitatif, dengan desain deskriptif analitik. Penelitian ini dilaksanakan disebuah kelas nonformal berupa rumah belajar dan bermain yang telah kami dirikan beberapa bulan lalu di daerah Bandung. Hasilnya, peneliti melihat tingkat literasi anak yang meningkat setelah menghasilkan beberapa produk, seperti puisi, cerita pendek, dan lainnya. Jika terus dilaksanakan, peneliti selaku generasi milenial yakin akan mampu mengubah pola pikir anak agar peduli dengan literasi, sehingga akan terciptanya generasi emas yang berpendidikan dan mampu memimpin dunia.
\end{abstract}

Kata Kunci: literasi, pendidikan, generasi emas 2045

\begin{abstract}
The quality of a generation is seen from the quality of an education. The rise of the issue of the current 2045 gold generation, gives hope to the millennial generation to prepare an educated golden generation in facing increasingly complex world problems. In preparing an educated generation, aspects that support this are needed. One of them is reading skills. Unfortunately, the level of literacy in Indonesian society, especially children, is still below average. Given the influence of the times, it can be predicted that future generations will opium technology and forget literacy. To prevent this from happening, researchers conducted research aimed at increasing children's literacy with productbased education. In this age of globalization, conventional teaching techniques such as lectures are not appropriate to use. Children must be active and can produce a work. By carrying out productbased education, children will automatically carry out reading activities for the sake of the creation of a product that must be produced. From this compulsion, researchers believe children will get used to doing literacy activities. In conducting this research, researchers used qualitative methods, with descriptive analytic designs. This research was conducted in a non-formal classroom in the form of a learning and play house that we had established a few months ago in the Bandung area. The result,
\end{abstract}


researchers saw the level of children's literacy that increased after producing several products, such as poetry, short stories, and others. If it continues to be carried out, researchers as the millennial generation are sure that they will be able to change the mindset of children to care about literacy, so that a golden generation with an education and leadership in the world will be created.

Keywords : literature, education, and golden generation 2045th

\section{PENDAHULUAN}

Pendidikan adalah aspek terpenting dalam kehidupan. Sebagai generasi milenial, pendidikan adalah sesuatu yang harus ditekuni dan dikembangkan. Sebuah bangsa tidak akan maju jika pendidikannya merosot. Kualitas sebuah generasi dilihat dari kualitas sebuah pendidikan. Manullang (2013) mengatakan bahwa kualitas SDM berhubungan dengan kualitas pendidikan. Nasib pendidikan harus dipersiapkan sejak dini, mengingat setiap tahun, bangsa kita akan menghadapi berbagai masalah yang kompeks, baik dari segi ekonomi, politik, terkikisnya sumber daya alam, dan sebagainya. Namun, bagaimana bisa generasi kita menghadapi semua itu jika pendidikan di negara ini sangat mengkhawatirkan, dari segi kualitas guru, kurangnya pemerataan sekolah di Indonesia, sampai rendahnya tingkat literasi masyarakat Indonesia, khususnya anak-anak.

Seperti yang telah dipaparkan mengenai pentingnya pendidikan di negara ini, maka pendidikan kini harus bisa membentuk generasi emas untuk menghadapi peliknya berbagai masalah yang akan datang di masa depan. Karena karakter Generasi Emas 2045 ditentukan oleh kualitas pendidikan. Maraknya isu mengenai generasi emas 2045 saat ini, memberikan harapan kepada generasi milenial untuk mempersiapkan generasi emas yang berpendidikan dalam menghadapi permasalahan dunia yang semakin kompleks. Dalam mempersiapkan generasi yang berpendidikan, diperlukan aspek yang menunjang hal tersebut. Salah satunya adalah keterampilan membaca.

Sayangnya, tingkat literasi masyarakat Indonesia, khususnya anak-anak masih di bawah ratarata. Dalam sebuah jurnal Masitoh (2018) Hasil survei yang dilakukan oleh Central Connecticut State University (2016) menunjukkan bahwa Indonesia ada pada urutan ke-60 dari 61 negara Skor PISA membaca, dan negara Indonesia berada di urutan ke 64 dari 72 Negara Skor INAP yang masih menunjukkan kategori kurang. Hal itu menunjukkan Indonesia berada pada level bawah dalam hal minat atau kegemaran membacanya. Sesuai dengan survei Internasional PIRLS (Progress in International Reading Literacy Study) pada tahun 2006, Indonesia termasuk dalam negara dengan kemampuan membaca yang rendah. Kemampuan membaca peserta didik Indonesia menempati posisi 41 dari 45 negara yang ikut serta. Rusia menempati posisi teratas dalam kemampuan membaca dengan skor 565, sedangkan Indonesia mendapatkan skor 405.

Mengingat pengaruh perkembangan zaman, dapat diprediksi generasi mendatang akan candu teknologi dan melupakan literasi. Agar tidak terjadi hal tersebut, peneliti melakukan penelitian yang bertujuan untuk meningkatkan literasi anak dengan pendidikan berbasis produk. Di zaman globalisasi ini, teknik mengajar konvensional seperti ceramah sudah tidak pas digunakan. Anak harus aktif dan bisa menghasilkan suatu karya. Dalam hal ini, peneliti membuat sebuah inovasi yaitu pendidikan berbasis produk untuk meningkatkan literasi anak, karena anak-anak adalah aset generasi masa mendatang. Maka, dengan menjalankan pendidikan berbasis produk, anak akan secara otomatis melakukan kegiatan membaca demi terciptanya suatu produk yang harus dihasilkan. Dari keterpaksaan 
tersebut, peneliti yakin anak-anak akan terbiasa melakukan kegiatan literasi. Dari penelitian ini diharapkan dapat memberikan dampak positif serta dapat meningkatkan kualitas pendidikan.

\section{TINJAUAN PUSTAKA}

\section{Skenario Generasi Indonesia 2045}

Seratus tahun setelah Indonesia merdeka, menjadi saat yang tepat bagi pemerintah dalam membangun karakter generasi emas 2045 sebagai kekuatan bagi bangsa Indonesia. Menurut Darman (2017), tahun 2010-2035 Indonesia memasuki periode bonus demografi, di mana usia produktif paling tinggi di antara usia anak-anak dan orang tua. Mengapa periode 2010-2035 sebagai periode bonus demografi? Hasil report Badan Pusat Statistik (BPS) tahun 2010 menunjukkan jumlah penduduk Indonesia usia muda lebih banyak dibandingkan dengan usia tua. Hasil tersebut memperlihatkan bahwa jumlah anak kelompok usia 0-9 tahun sebanyak 45,93 juta, sedangkan anak berusia 10-19 tahun berjumlah 43,55 juta jiwa. Pada tahun 2045 diproyeksikan, mereka yang berusia 0-9 tahun akan berusia 35-45 tahun, sedangkan yang berusia 10-20 tahun berusia 45-54 tahun.

Menurut Darman (2017) menyimpulkan bahwa pada tahun 2045 nanti, tepat Indonesia berusia 100 tahun, negara ini sudah memiliki generasi-generasi penduduk warga dunia yang bersifat transkultural, namun harus tetap hidup dan berkembang dalam jati diri dan budaya Indonesia sebagai sebuah bangsa yang bermartabat. Sesuai dengan prediksi pemerintah bahwa generasi emas adalah kondisi jumlah penduduk Indonesia yang diperkirakan berjumlah 88 juta jiwa usia 0-19 tahun yang lebih banyak dibandingkan usia tua.

Generasi emas berkaitan dengan bagaimana keadaan generasi Indonesia ketika berusia 100 tahun merdeka. Sebagai bangsa yang besar dengan modalitas yang sangat luar biasa, baik sumber daya manusia, sumber daya alam, sumber daya kultural, maupun sumber daya lainnya; sudah saatnya dikelola dan dimanfaatkan dengan sebaik-baiknya untuk kemakmuran dan kesejahteraan rakyat. Lahirnya generasi emas menjadi harapan bagi bangsa Indonesia untuk menjadi bangsa yang besar, bermartabat, dan kompeten pada tingkat global.

\section{Pengertian Pendidikan}

Setelah mengetahui tentang generasi emas, tentunya banyak tantangan bagi generasi emas untuk mewujudkan momentum "emas" tersebut. Salah satu kunci dari segala polemik dalam dunia global adalah pendidikan. Beberapa ahli yang mendefinisikan pendidikan, salah satunya adalah menurut John Dewey, pendidikan adalah proses tanpa akhir (education in the process without end). Dan pendidikan merupakan proses pembentukan kemampuan dasar yang fundamental, baik menyangkut daya pikir (daya intelektual) maupun daya emosional (perasaan) yang diarahkan kepada tabiat manusia dan kepada sesamanya.

Edwards (1998) suggests that more open countries have experienced faster productivity growth rates, with education playing an important role, as countries with a more developed educational systemare arguably betterat innovating and absorbing new ideas.

Edward menjelaskan bahwa banyak negara terbuka telah mengalami tingkat pertumbuhan produktivitas yang lebih cepat dengan pendidikan yang memainkan peran penting, negara-negara 
dengan sistem pendidikan yang dikembangkan lebih baik bisa dikatakan lebih baik dalam berinovasi dan menyerap ide-ide baru.

Ditinjau dari sudut hukum, definisi pendidikan berdasarkan Undang-Undang RI Nomor 20 Tahun 2003 tentang Sisdiknas, Pasal 1 ayat (1) bahwa "Pendidikan adalah suatu usaha sadar dan terencana untuk mewujudkan suasana belajar dan proses pembelajaran agar peserta dididik secara aktif mengembangkan potensi dirinya untuk memiliki kekuatan spiritual keagamaan, pengendalian diri, kepribadian, kecerdasan, akhlak mulia, serta keterampilan yang diperlukan dirinya, masyarakat, bangsa, dan negara".

Berlatarbelakang dari definisi pendidikan yang telah dijabarkan pada paragraf di atas, dapat dipahami bahwa pendidikan merupakan proses yang terus menerus ada dan tidak pernah berhenti. Di dalam proses pendidikan ini, keluhuran martabat manusia dipegang erat karena manusia adalah subyek dari pendidikan.

\section{Literasi}

Kajian mengenai literasi dalam penelitian ini lebih berfokus pada keterampilan membaca dan menulis. Kini, literasi memiliki makna dan implikasi dari keterampilan membaca dan menulis dasar ke pemerolehan dan manipulasi pengetahuan melaui teks tertulis, dari analisis metalinguistik unit gramatikal ke struktur teks lisan dan tertulis, dari dampak sejarah manusia ke konsekuensi filosofis dan sosial pendidikan barat (Goody \& Watt, 1963; Chafe, 1987; Olson, 1991; Ong, 1992).

Kemampuan berbahasa Indonesia, termasuk keterampilan literasi perlu mendapatkan penekanan dalam kompetensi, pemilihan materi dan distribusinya di sekolah dasar maupun sekolah menengah. Sekolah dasar menjadi dasar pembelajaran literasi karena sekolah dasar merupakan awal seorang anak belajar membaca dan menulis (Nurdiyanti, 2010).

Kemampuan membaca mempunyai peran dan menjadi salah satu kunci dalam kesuksesan di kehidupan seseorang karena setiap informasi dan pengetahuan apapun yang diperoleh tidak terlepas dari kegiatan membaca. Tidak berbeda dengan membaca, menulis pun memiliki peran tersendiri bagi kehidupan Kegiatan literasi lah yang akan menjadi jawaban dari penerapan pendidikan era 2045 nanti.

\section{METODE}

Desain yang digunakan dalam penelitian ini adalah desain deskriptif analitik dengan pendekatan kualitatif. Meleong (2010) menyatakan bahwa metodologi kualitatif adalah prosedur penelitian yang akan menghasilkan data-data deskriptif berupa kata-kata yang tertulis atau lisan dari orang-orang yang berperilaku yang diamati. Metode deskripsi disebut juga metode dengan pengumpulan data berupa kata-kata, gambar, dan yang bukan deretan angka-angka serta tidak bersifat perhitungan data statistik.

Subjek atau informan dalam peneltian ini adalah anak-anak usia Sekolah Dasar dan Sekolah Menengan Pertama yang tergabung dalam The House of Rising Star. Informan berjumlah 5 orang yang merupakan 2 siswa Sekolah Dasar dan 3 siswa Sekolah Menengah Pertama. Data dalam penulisan karya tulis ini diambil dari sumber-sumber yang berasal dari jurnal ilmiah nasional dan internasional, buku-buku, artikel, dan teori yang relevan dengan topik penulisan. Sedangkan untuk data lapangan, data yang dikumpulkan berupa hasil karya peserta The House Of Rising Star. 
Teknik pengumpulan data dalam karya tulis ini adalah dengan pengumpulan data sekunder berupa jurnal ilmiah nasional dan internasional, buku-buku, artikel, dan teori yang relevan dengan topik penulisan. Sedangkan untuk data primer, pengumpulan data berupa hasil karya peserta The House Of Rising Star. Serta data-data dokumentasi dengan cara mencari bukti-bukti dari sumber non manusia terkait dengan objek yang (Afifuddin dan Saebani: Sugiarto, 2015). Analisis data dilakukan dengan model analisis deskriptif yakni dengan menganalisis data primer yang didapatkan dari subjek penelitian. Data yang dianalisis dikaitkan dengan teori hingga menghasilkan sebuah jawaban untuk rumusan masalah. Langkah terakhir adalah membuat kesimpulan atas jawaban dari rumusan masalah.

\section{PEMBAHASAN}

\section{Proses Peningkatan Literasi Dengan Pendidikan Berbasis Produk}

Pendidikan berbasis produk adalah sebuah strategi pembelajaran dengan menyuruh siswa untuk menghasilkan sebuah produk. Ketika disangkutpautkan dengan literasi, maka produk yang dimaksudkan haruslah berhubungan dengan peningkatan literasi siswa tersebut. Mengingat dasar peneliti adalah bahasa dan sastra, maka kami bermaksud untuk mengembangkan literasi siswa di bidang bahasa dan sastra. Dalam hal ini, kami menitikberatkan kepada pembelajaran Bahasa Indonesia seperti puisi dan cerita pendek. Sebelumnya, kelas The House of Rising Star menjadi wadah bagi siswa dalam meningkatkan potensi dalam berbagai bidang atau mata pelajaran. Namun, karena kami ingin meneliti peningkatan literasi siswa, maka kami memfokuskan pada literasi siswa di mata pelajaran Bahasa Indonesia. Dengan adanya pendidikan berbasis produk, maka siswa akan dituntut untuk selalu membuat produk dengan membaca literatur terlebih dahulu. Contohnya, pada produk puisi, siswa dituntut untuk sebelumnya membaca berbagai puisi. Begitupun dengan cerpen, sebelum membuat, mereka dituntut untuk membaca sebuah cerita anak. Literasi ini dimaksudkan agar siswa bisa mudah menemukan inspirasi untuk membuat karya, juga untuk menambah kosakata dalam penulisan mereka. Maka, dengan dituntut untuk selalu membuat produk, secara tidak langsung, tingkat literasi mereka akan meningkat. Seperti pada sebuah peribahasa "Bisa karena terbiasa".

Proses yang peneliti lakukan adalah dengan membuat sebuah jadwal pembelajaran, berupa pematerian dan pengumpulan produk siswa. Kegiatan penelitian ini berlangsung dalam seminggu. Dalam dua pertemuan pematerian, yaitu awal dan akhir penelitian. Peneliti menyelipkan sebuah observasi untuk mengetahui bagaimana minat siswa terhadap literasi sebelum dan sesudah diberikan perlakuan (berupa suruhan untuk membuat sebuah produk). Peneliti melakukan observasi karena metode yang digunakan adalah penelitian kualitatif. Dari observasi tersebut, maka akan terlihat bagaimana peningkatan literasi siswa melalui pendidikan berbasis produk ini.

Berikut akan ditampilkan rencana jadwal pembelajaran pendidikan berbasis produk di kelas nonformal The House of Rising Star yang dilakukan dari tanggal 2 Februari sampai 10 Februari 2019. 
Tabel 1 Jadwal Kegiatan

\begin{tabular}{|l|l|l|l|l|l|l|l|l|l|}
\hline \multirow{2}{*}{ Nama Kegiatan } & \multicolumn{7}{|c|}{ Tanggal } \\
\cline { 2 - 13 } & $\mathbf{2}$ & $\mathbf{3}$ & $\mathbf{4}$ & $\mathbf{5}$ & $\mathbf{6}$ & $\mathbf{7}$ & $\mathbf{8}$ & $\mathbf{9}$ & $\mathbf{1 0}$ \\
\hline Observasi awal & & & & & & & & & \\
\hline Pematerian & & & & & & & & & \\
\hline $\begin{array}{l}\text { Pembuatan dan } \\
\text { pengumpulan } \\
\text { Produk }\end{array}$ & & & \multicolumn{2}{|c|}{} & & & & \\
\hline Penilaian produk & & & & & & & & & \\
\hline Observasi akhir & & & & & & & & & \\
\hline
\end{tabular}

Berdasarkan tabel di atas, tanggal 2 Februari 2019 merupakan observasi awal, peneliti mencari dan menemukan masalah siswa mengenai membaca, khususnya pada mata pelajaran Bahasa Indonesia, apa yang mereka minati dan apa kendalanya. Keesokan harinya diadakan pematerian dengan membahas cerita pendek anak, legenda, dan puisi. Tanggal 4 sampai 8 Februari 2019, siswa membuat sebuah produk dengan jenis, tema, dan judul karya yang berbeda-beda. Tanggal 9 Februari 2019 merupakan penilaian seluruh karya. Di sini dapat terlihat perbedaan literasi siswa, dari jumlah karya yang dikumpulkan dan kualitas karya dari hari ke hari (membuktikan tingkat membaca dari hari ke hari). Terakhir, tanggal 10 Februari 2019 merupakan observasi akhir, di sinilah penentu apakah siswa menjadi lebih minat membaca atau tidak. Observasi ini juga menjadi penentu apakah pendidikan berbasis produk bisa meningkatkan literasi siswa atau tidak.

\section{Jenis Produk Literasi Karya Siswa}

Pada penelitian ini karya yang dihasilkan oleh siswa yang tergabung dalam The House of Rising Star berupa tulisan yang sesuai dengan kemampuan dengan subjek penelitian. Mereka tidak dibatasi dari segi format penulisan, tetapi dibatasi dari segi genre tulisan. Melihat dari situasi dan kondisi para siswa, maka peneliti membatasi subjek hanya menulis puisi dan cerpen/cerita mini dengan tema bebas. Sedangkan untuk teknik penulisan lebih diarahkan dengan menulis tangan. Melalui cara tersebut, diharapkan mengefesiensi siswa dalam berkarya.

Tabel 2 Produk Puisi

\begin{tabular}{|l|l|l|l|l|}
\hline No & Tanggal & Siswa (inisial) & Judul & Nilai \\
\hline 1. & $4 / 2 / 2019$ & $\mathrm{~S}$ & $\begin{array}{l}\text { Kembalikan } \\
\text { Duniaku }\end{array}$ & 3 Bintang \\
\hline 2. & $4 / 2 / 2019$ & $\mathrm{~K}$ & Kasih Sayang & 3 Bintang \\
\hline
\end{tabular}




\begin{tabular}{|l|l|l|l|l|}
\hline & & & Seorang Ayah & \\
\hline 3. & $4 / 2 / 2019$ & $\mathrm{D}$ & Kasih Sayang Ayah & 3 Bintang \\
\hline 4. & $5 / 2 / 2019$ & $\mathrm{~S}$ & Sang Mentari & 5 Bintang \\
\hline 5. & $5 / 2 / 2019$ & $\mathrm{~K}$ & Ibuku Pahlawanku & 4 Bintang \\
\hline 6. & $5 / 2 / 2019$ & $\mathrm{D}$ & Ibu Yang Terbaik & 3 Bintang \\
\hline 7. & $5 / 2 / 2019$ & $\mathrm{Dz}$ & Ibu & 3 Bintang \\
\hline 8. & $5 / 2 / 2019$ & $\mathrm{Da}$ & Kasih Sayang Ibu & 4 Bintang \\
\hline
\end{tabular}

Tabel 3

\section{Produk Cerita}

\begin{tabular}{|l|l|l|l|l|}
\hline No & Tanggal & Siswa (inisial) & Judul & Nilai \\
\hline 1. & $6 / 2 / 2019$ & $\mathrm{~S}$ & Jalan Keliling Jawa & 3 Bintang \\
\hline 2. & $6 / 2 / 2019$ & $\mathrm{~K}$ & $\begin{array}{l}\text { Aktivitas Selama } \\
\text { Seminggu }\end{array}$ & 2 Bintang \\
\hline 3. & $6 / 2 / 2019$ & $\mathrm{D}$ & $\begin{array}{l}\text { Liburan Saat Aku di } \\
\text { Kampung Ibuku }\end{array}$ & 2 Bintang \\
\hline 4. & $6 / 2 / 2019$ & $\mathrm{Dz}$ & Rasa Liburanku & 3 Bintang \\
\hline 5. & $6 / 2 / 2019$ & $\mathrm{Da}$ & $\begin{array}{l}\text { Liburan ke Pelabuhan } \\
\text { Ratu }\end{array}$ & 4 Bintang \\
\hline 6. & $7 / 2 / 2019$ & $\mathrm{~S}$ & Miyah & 5 Bintang \\
\hline 7. & $7 / 2 / 2019$ & $\mathrm{D}$ & Mila Si Tempakul & 4 Bintang \\
\hline 8. & $7 / 2 / 2019$ & $\mathrm{Dz}$ & Sacrifice & 2 Bintang \\
\hline 9. & $7 / 2 / 2019$ & $\mathrm{Da}$ & Rekan & 5 Bintang \\
\hline
\end{tabular}

Berdasarkan data tabel yang sudah dipaparkan di atas, dapat dikatakan bahwa siswa yang tergabung dalam The House of Rising Star ini memiliki kemampuan dan potensi dalam menghasilkan produk tulisan berupa puisi dan cerita setelah diberikan pembelajaran secara nonformal terkait pembelajaran literasi, khususnya menulis. Pada produk tulisan berbentuk puisi, hanya dua orang anak yang tidak mengumpulkan tugas menulis yang diberikan peneliti. Sedangkan untuk produk tulisan berbentuk cerita hanya satu orang yang tidak mengumpulkan. Namun, dalam pembuatan karya berupa produk ini peneliti menilai menggunakan sistem bintang yakni sesuai dengan visi misi The House of Rising Star. 
Tabel 4 Intrumen Penilain

\begin{tabular}{|l|l|}
\hline \multicolumn{1}{|c|}{ Bobot } & \multicolumn{1}{|c|}{ Keterangan } \\
\hline 1 Bintang & Kurang \\
\hline 2 Bintang & Cukup \\
\hline 3 Bintang & Baik \\
\hline 4 Bintang & Sangat Baik \\
\hline 5 Bintang & Terbaik \\
\hline
\end{tabular}

Proses penilaian ini diberikan nama bintang untuk menarik minat siswa dalam mengumpulkan sebanyak-banyaknya bintang yang mereka mampu. Pengumpul bintang yang paling banyak akan mendapat apresiasi lebih dari peneliti.

\section{Gambar 1 Karya Siswa}
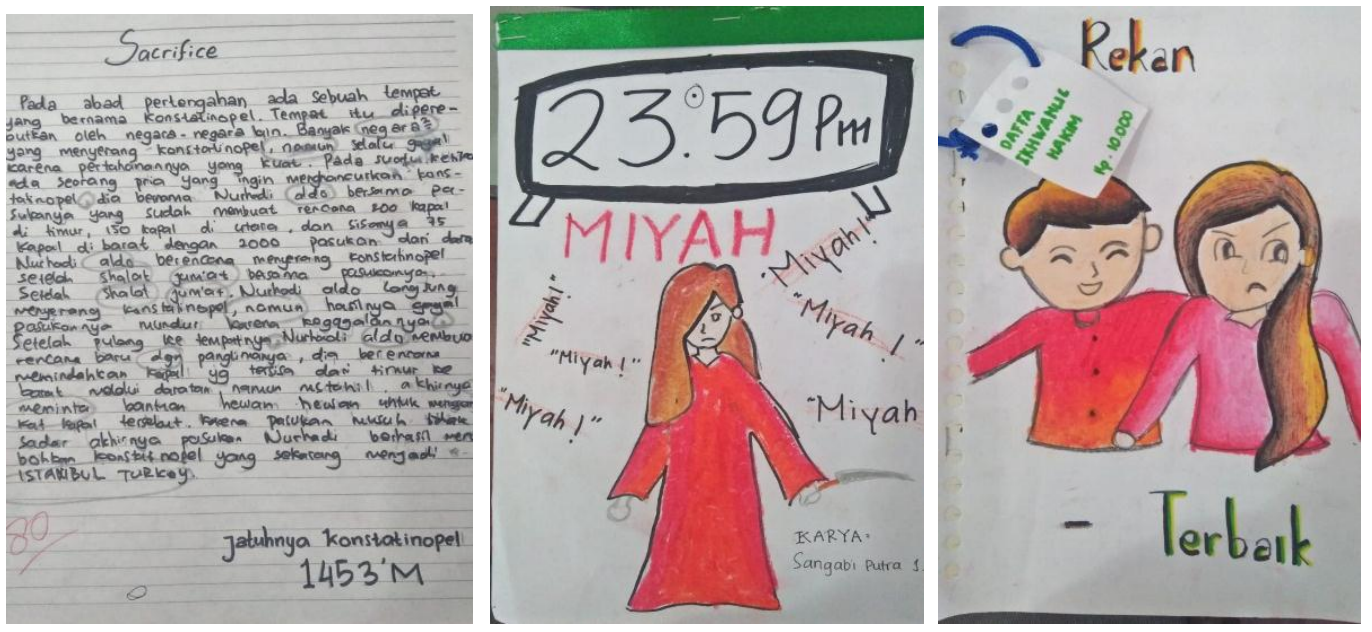

Terlihat pada gambar tersebut bahwa siswa yang menjadi responden dalam penelitian begitu bersemangat sekali dalam berkarya. Bentuk totalitas dapat dilihat pada gambar tersebut.

\section{Manfaat atau Dampak Penerapan Pendidikan Berbasis Produk}

Sebuah proses awal(ide) akan menuju proses akhir(karya). Setiap proses tersebut akan berimplikasi dan berdampak. Dalam penelitian ini, dampak atau pengaruh yang dihasilkan adalah dampak positif yang merupakan manfaat dari penerapan pendidikan berbasis produk yang dilakukan peneliti. Manfaat-manfaat ini dikemukakan atau disampaikan oleh para siswa The House of Rising Star yang menjadi objek kajian peneliti.

Pertama, setelah diberikan pancingan oleh peneliti, anak-anak menjadi suka membaca dan menulis. Pada awalnya, anak-anak lebih menyukai gadget dibadingkan buku. Akan tetapi, peneliti 
memberi waktu kepada mereka untuk mencintai buku atau karya-karya lainnya. Peneliti menghindari sikap memaksa karena anak-anak cenderung akan mudah teralihkan kepada hal lainnya jika dipaksakan. Setelah diberikan perlakuan atau pengajaran berbasis produk, perlahan anak-anak menjadi suka kemudian lebih cermat untuk menyimak bahan bacaan yang diberikan. Hal ini akan berguna untuk mereka ketika berada di lingkungan sekolah maupun luar sekolah.

Kedua, dengan penerapan pendidikan berbasis produk, anak-anak memiliki daya saing untuk saling berlomba menghasilkan karya yang bisa diapresiasi dengan tanda bintang. Anak-anak percaya dengan mendapatkan bintang, ilmu yang mereka terima telah terserap dan melekat dalam ingatan mereka. Mereka menganggap bintang adalah sesuatu yang sangat berharga, seperti sebuah impian. Hal ini merupakan proses yang diciptakan untuk memotivasi mereka dalam berkarya.

Ketiga, dengan proses pembelajaran yang seperti diskusi, anak-anak mengaku lebih mudah dalam bersosialisasi karena mereka tidak dibatasi oleh jabatan, seperti guru dan siswa. Para peneliti yang merupakan pengajar menjadikan anak-anak seperti teman dalam berdiskusi. Hal inilah yang memancing jiwa sosial mereka untuk peka dan aktif dalam mengeluarkan pendapat.

\section{PENUTUP \\ Simpulan}

Berdasarkan hasil analisis yang telah dilaksanakan, peneliti menarik benang merah bahwa dengan menerapkan pendidikan berbasis produk pada kelas nonformal The House of Rising Star, maka tingkat literasi anak yang diteliti meningkat, walaupun percobaan ini hanya baru dilaksanakan kurang lebih selama seminggu. Butuh beberapa waktu lagi agar menghasilkan hasil yang komperhensif. Yang menjadi bukti ketercapaian penelitian kami adalah bukan dari penilaian berapa jumlah nilai atau berapa bintang yang didapat, itu hanya justifikasi yang kesekian. Namun, yang menjadi tiitk tekan adalah ketika setiap siswa dituntut untuk menghasilkan sebuah produk, maka secara terpaksa mereka dituntut pula untuk membaca. Dari keterpaksaan tersebutlah dapat dilihat dari hasil observasi bahwa sebelum diterapkannya pendidikan berbasis produk ini dan setelahnya, akan terlihat perubahan yang cukup segnifikan. Dari hasil tersebut maka seluruh siswa mengaku lebih senang dan tertarik terhadap kegiatan literasi atau membaca setelah kurang lebih seminggu ini mereka membuat beberapa produk yaitu karya sastra. Selain berdampak pada minat membaca yang meningkat, semangat dan kualitas mereka dalam membuat karya pun semakin meningkat. Maka dengan ini, inovasi pendidikan berbasis produk dinyatakan efektif dalam meningkatkan literasi anak.

\section{Saran}

Saat ini, yang baru sempat peneliti lakukan sebuah penelitian adalah di kelas nonformal, karena peneliti ingin memanfaatkan potensi murid yang peneliti ajar di kelas nonformal ini. Namun, dengan begitu, bukan berarti inovasi ini hanya berlaku di kelas nonformal. Maka, peneliti memberikan rekomendasi kepada pengajar atau pendidik kelas formal untuk bisa mengaplikasikan metode ini kepada siswanya. Tentu disesuaikan pula dengan kurikulum dan silabusnya. Bagi peserta didik atau siswa, peneliti merekomendasikan agar memerhatikan pentingnya literasi, lalu tentu meningkatkannya, karena mengingat betapa penting manfaat dari literasi tersebut. 


\section{DAFTAR PUSTAKA}

Chafe, W. (1994). Discourse, Consciusness, and Time. Chicago: The University of Chicago Press.

Darman, R.A. (2017). Mempersiapkan Generasi Emas Indonesia Tahun 2045 Melalui Pendidikan Berkualitas. Jurnal Edik Informatika, 3(2), hlm. 73-87.

Edward, S. (1998). Openness, Productivity and Growth: What Do We Really Know? Econ. J. 108, hlm. 383-398.

Goody, J. \& Watt, I. (1963). The Consequences of Literacy. Contemporary Studies in Society and History 5.

Kopeuw, P.M. (2015). Mimpi Memiliki Generasi Emas Sentani. Jakarta: tp. Manullang.

Manullang, Belferik. (2013). Grand Desain Pendidikan Karakter Generasi Emas 2045. Jurnal Pendidikan Karakter, 3 (1), hlm. 1-14.

Masitoh, Siti. (2018). Blended Learning Berwawasan Literasi Digital Suatu Upaya Meningkatkan Kualitas Pembelajaran dan Membangun Generasi Emas 2045. Proceedings of The ICECRS, 1 (3), hlm. 1334.

Meleong, L.J. (2010). Metodologi Penelitian Kualitatif. Bandung : Remaja Rosda Karya.

Nurdiyanti, E. \& Suryanto, E. (2010). Pembelajaran Literasi Mata Pelajaran Bahasa Indonesia pada Siswa Kelas V Sekolah Dasar. Jurnal Paedagogia, 13(2), hlm. 115-128.

Olson, D.R. (1991). Literacy and The Rise of Modern Science. Dalam D.R. Olson \& N. Torrance (Eds). Literacy and Orality. Cambridge: CUP.

Ong, W.J.(1992). Writing is a Technology that Restructure Thought. Dalam P. Downing, S.D. Lima \& M. Noonan (Eds). The Linguistics of Literacy. Amsterdam: John Benjamins.

Pemerintah Indonesia. 2003. Undang-Undang No. 20 Tahun 2003 tentang Sistem Pendidikan Nasional. Lembaran RI Tahun 2003, No.78. Jakarta: Sekretariat Negara.

Ruhaena, Lisnawati. Model Multisensori: Solusi Stimulasi Literasi Anak Prasekolah. Jurnal Psikologi, 42 (1), hlm. 47-60.

Sugiarto, Eko. 2015. Metode pengumpulan data menurut sugiyono menyusun proposal penelitian kualitatif skripsi dan tesis. Yogyakarta: Suaka Media. 